\title{
Removal of Au(III) from Aqueous Au(III) Solution Using Microbial Cells by Biosorption and Biomineralization
}

\author{
Takehiko Tsuruta*, Ichiro Maeda \\ Department of Life and Environmental Science, Hachinohe Institute of Technology, Hachinohe, Japan \\ Email: *tsuruta@hi-tech.ac.jp
}

How to cite this paper: Tsuruta, T. and Maeda, I. (2021) Removal of Au(III) from Aqueous Au(III) Solution Using Microbial Cells by Biosorption and Biomineralization. Advances in Microbiology, 11, 199-212. https://doi.org/10.4236/aim.2021.114015

Received: March 14, 2021

Accepted: April 24, 2021

Published: April 27, 2021

Copyright $\odot 2021$ by author(s) and Scientific Research Publishing Inc. This work is licensed under the Creative Commons Attribution International License (CC BY 4.0).

http://creativecommons.org/licenses/by/4.0/

\begin{abstract}
The demand for gold has increased in the medical and industrial fields. Therefore, recycling this element has become essential. Although gold recovery using microbes has been investigated, there is a dearth of these studies on identifying the species that have a high gold recovering ability. Herein, gold (III) removal by microbial cells was investigated to obtain basic information on gold (III) removal from aqueous systems by biosorption and biomineralization. High amounts of gold were removed from the solution containing hydrogen tetrachloroaurate (III) by the tested microbial species, which included bacteria, fungi and yeasts. However, relatively less gold was recovered by biosorption using gram-positive bacteria, fungi, and yeasts than that by gram-negative bacteria. Therefore, we first examined gold (III) removal by biosorption and biomineralization by Pseudomonas saccharophila, which was able to remove the largest amounts of gold (III). Incubation time and other factors affecting gold removal were then examined. P. saccharophila removed about half the amount of gold (III) by biosorption and the remaining half by biomineralization.
\end{abstract}

\section{Keywords}

Gold (III) Biosorption, Gold (0) Biomineralization, Microorganism, Peudomonas saccharophila

\section{Introduction}

The demand for gold has significantly increased because of its increasing use in the electrical industry and the development of gold-containing drugs [1]. Therefore, recycling this valuable resource has become a subject of great interest. 
Several researchers have investigated gold recovery using microbial cells, such as bacteria [2], fungi [3] [4] [5], yeasts [6], and algae [7] [8]. However, there is little information on the species of microorganisms that have a high gold adsorbing ability.

We previously reported that several microorganisms adsorb gold, and screened resting 75 microbial strains (19 actinomycetes, 25 bacteria, 17 fungi, and 14 yeasts) from a hydrogen tetrachloroaurate (III)-containing solution [9]. Hydrogen tetrachloroaurate (III) is used for medical and ceramic materials. Of the tested microorganisms, some gram-negative bacteria showed gold-adsorption ability. These microorganisms adsorbed over 330 mol gold per gram of microbial cells (dry wt.) from the solution containing hydrogen tetrachloroaurate (III) within 1 h. The gold adsorbed from hydrogen tetrachloroaurate (III) solution by gramnegative bacteria was higher than that adsorbed by gram-positive bacteria, actinomycetes, fungi, and yeasts. These results are in contrast to those reported for the adsorption of the amount of lithium [10], cadmium [11], uranium [12], thorium [13], and rare earth metals [14], these were adsorbed in higher amounts by gram-positive bacteria compared to the gram-negative bacteria, fungi, and yeasts. The results show that gram-positive bacteria can adsorb a large amount of positively-charged metal ions, while gram-negative bacteria can adsorb a large amount of negatively-charged complex ions [9]-[14]. Gold (III) exists as a negatively charged-complex ion in an acidic solution. The negative charge of the gram-positive bacterial cell surface is higher than that of the gram-negative bacteria, because teichoic acid levels are higher in the former at a neutral pH [15] [16] [17]. In other words, the positive charge of the gram-negative bacterial cell surface is higher than that of the gram-positive bacterial cell surface. Accordingly, negatively-charged gold complex ions bond more strongly on the positively-charged gram-negative bacterial cell surface [9].

We investigated the effects of $\mathrm{pH}$, external gold concentration, cell amount, and gold contact time in Pseudomonas maltophilia, which adsorbs large amounts of gold from a hydrogen tetrachloroaurate (III) containing solution [9].

In this study, the investigation was performed to improve gold removal by biosorption and biomineralization from aqueous systems using microbial cells.

\section{Material and Methods}

\subsection{Culture of Microorganisms}

The strains used in this research were generously donated by the IAM Culture Collection, Center for Cellular and Molecular Research, the Institute of Molecular and Cellular Biosciences, the University of Tokyo (IAM), the Faculty of Engineering, Hiroshima University (HUT), and the Faculty of Agriculture, Hokkaido University (AHU). All chemicals (guaranteed reagents) used in this study were obtained from Nacalai Tesque (Kyoto, Japan).

The bacterial culture medium contained $3 \mathrm{~g} / \mathrm{L}$ meat extract, $5 \mathrm{~g} / \mathrm{L}$ peptone, and $5 \mathrm{~g} / \mathrm{L} \mathrm{NaCl}$ in deionized water [9]-[14]. The medium for growing actinomy- 
cetes, fungi, and yeasts contained $4 \mathrm{~g} / \mathrm{L}$ yeast extract, $10 \mathrm{~g} / \mathrm{L}$ malt extract, and 4 $\mathrm{g} / \mathrm{L}$ glucose in deionized water with $\mathrm{pH} 7.1$ (for actinomycetes) and $\mathrm{pH} 5.7$ (for fungi and yeasts) [9]-[14]. The microorganisms were maintained on agar slants and grown in $300 \mathrm{~mL}$ of the medium in a $500-\mathrm{mL}$ flask with continuous shaking $\left(120 \mathrm{rpm}\right.$ ) for $72 \mathrm{~h}$ at $30^{\circ} \mathrm{C}$. Cells were collected by centrifugation (for bacteria and yeasts) at 15,000 rpm for 3 times, or by filtration through a filter paper (No. 2, Advantec Co. Ltd., Tokyo, Japan) (for actinomycetes and fungi), which is washed thoroughly with deionized water, and then used in gold removal experiments.

\subsection{Gold (III) Removal Experiment}

Unless otherwise stated, the removal experiments were conducted as follows. Resting microbial cells [15 mg dry weight basis for tetrachloroaurate (III)] were suspended in $100 \mathrm{~mL}$ solution containing $50 \mathrm{mg} / \mathrm{L}(254 \mu \mathrm{M})$ gold $(\mathrm{pH} 3.0)$ containing hydrogen tetrachloroaurate (III). The suspension was shaken for $72 \mathrm{~h}$ at $30^{\circ} \mathrm{C}$. The resting microbial cells were then removed by filtration through a membrane filter $(0.2 \mu \mathrm{m}$ pore size). The gold removed by the cells was determined by measuring the gold content in the filtrate with an atomic absorption analysis quantometer (AA-6300, Shimadzu Corporation, Kyoto, Japan). Absorption spectrometry analysis of the filtrate of the gold removal using varying $P$. saccharophila IAM1504 amounts was measured by UV and visible spectrophotometer (V-650; JASCO Corporation, Tokyo, Japan) at wavelengths ranging from $200-870 \mathrm{~nm}$. P. saccarophia and C. krusei cell surfaces were observed via scanning electron microscopy (SEM) and x-ray fluorescence (XRF) analysis (SEM-EDX S-4300, Hitachi High-Tech Corporation, Tokyo, Japan). Gold reduced by each microbial cell was frozen using a freeze dryer (FDU-830, EYELA Corporation, Tokyo, Japan) for $20 \mathrm{~h}$ in vacuo. The samples after deposition in vacuo for $24 \mathrm{~h}$ were observed SEM and XRF.

\subsubsection{Screening of Microorganisms for Gold (III) Removal from the Solution for $72 \mathrm{~h}$}

Resting cells ( $15 \mathrm{mg}$ on a dry wt. basis) were suspended in $100 \mathrm{~mL}$ solution (pH 3.0) containing hydrogen tetrachloroaurate (III) $(254 \mu \mathrm{M}, \mathrm{pH} 3.0)$ for $72 \mathrm{~h}$ at $30^{\circ} \mathrm{C}$.

\subsubsection{Gold Removal as a Function of Time Using P. saccharophila IAM1504}

Resting cells ( $15 \mathrm{mg}$ on a dry wt. basis) were suspended in $100 \mathrm{~mL}$ solution ( $\mathrm{pH}$ 3.0) containing hydrogen tetrachloroaurate (III) $(254 \mu \mathrm{M}, \mathrm{pH} 3.0)$ for tenures varying from $5 \mathrm{~min}$ to $68 \mathrm{~h}$ at $30^{\circ} \mathrm{C}$.

\subsubsection{Effect of pH on Gold (III) Removal Using P. saccharophila IAM1504}

Resting cells (15 mg on a dry wt. basis) were suspended in a $100 \mathrm{~mL}$ solution (pH from 1 to 5$)$ containing hydrogen tetrachloroaurate (III) $(254 \mu \mathrm{M})$ for 1 or $72 \mathrm{~h}$ at $30^{\circ} \mathrm{C}$. 


\subsubsection{Effect of Cell Amount on Gold (III) Removal Using P. saccharophila IAM1504}

Resting cells (from 5 to $23 \mathrm{mg}$ on a dry wt. basis) were suspended in a $100 \mathrm{~mL}$ solution ( $\mathrm{pH} 4.0)$ containing hydrogen tetrachloroaurate (III) $(254 \mu \mathrm{M})$ for $1 \mathrm{~h}$ or $72 \mathrm{~h}$ at $30^{\circ} \mathrm{C}$.

\subsubsection{Effect of Gold (III) Concentration on Gold (III) Removal Using P. saccharophila IAM1504}

Resting cells (15 mg on a dry wt. basis) were suspended in a $100 \mathrm{~mL}$ solution (pH 3.0) containing $0 \mathrm{mg} / \mathrm{L}, 50 \mathrm{mg} / \mathrm{L}, 100 \mathrm{mg} / \mathrm{L}, 150 \mathrm{mg} / \mathrm{L}, 200 \mathrm{mg} / \mathrm{L}$, or 250 $\mathrm{mg} / \mathrm{L}$ gold (III) as hydrogen tetrachloroaurate (III) $(\mathrm{pH} 4.0)$ for $1 \mathrm{~h}$ or $72 \mathrm{~h}$ at $30^{\circ} \mathrm{C}$.

\section{Results and Discussion}

\subsection{Microorganim Screening for Gold (III) Removal from the Solution for $72 \mathrm{~h}$}

To determine the ability of different microbial cells to remove a larger amount of gold (III), 48 microorganism strains ( 5 actinomycetes, 19 bacteria, 13 fungi, and 11 yeasts) were screened. Gram-negative bacteria, such as $P$. maltophilia, have been reported to remove a large amount of gold (III) from an aqueous hydrogen tetrachloroaurate (III) solution ( $\mathrm{pH} 3$ ) in $1 \mathrm{~h}$ at $30^{\circ} \mathrm{C}$ by biosorption [9]. The highest adsorption of gold (III) occurred at $\mathrm{pH} 3.0$ using P. maltophilia [9]. Therefore, the $\mathrm{pH}$ of the solution was adjusted to 3.0 in this screening process, additionally, we identified some microorganisms that removed a larger amount of gold (III) and reducted the gold in solution to gold (0) in the preliminary experiment.

The ability of the microbial cells to remove gold significantly varied (Tables 1-5). Of the tested microorganisms, high gold removal ability was observed in all microorganisms. Nocardia erythropolis IAM1399 (gram-positive bacteria), Eschelichia coli IAM1264, P. maltophilia IAM1554, and P. saccharophila IAM1504 (gram-negative bacteria), Aspergillus niger IAM2534, Chaetomium globosum IAM9272 and IAM9427 (fungi), and Candida. utilis IAM4220, Pichia farinosa IAM12223, and Saccharomyces cerevisiae AHU3818 (yeasts) removed gold $>1200$ $\mu \mathrm{mol} / \mathrm{g}$ dry cell weight in $72 \mathrm{~h}$ at $30^{\circ} \mathrm{C}$. In the results of our previous study [9], the amount of gold (III) removed by gram-negative bacteria was higher than that by the gram-positive bacteria, actinomycetes, fungi, and yeasts. The maximum amount of gold (III) removal was $360 \mu \mathrm{mol} / \mathrm{g}$ dry cell weight in $1 \mathrm{~h}$ at $30^{\circ} \mathrm{C}$. Therefore, many microorganisms were able to remove large amounts of gold (III) after a long incubation time.

As these results were contact time-dependent, we hypothesized that the reaction mechanisms may be different. The solution was almost colorless for $1 \mathrm{~h}$, however, it changed to dark colors like -violet or -dark green after longer removal time. Gold removal within $1 \mathrm{~h}$ likely occurred by biosorption, although longer incubation time $(72 \mathrm{~h}$ ) caused the reduction of gold (III) to zero-valent gold. 
Table 1. Removal of gold by gram-poitive bacteria.

\begin{tabular}{cc} 
Species & $\begin{array}{c}\text { Au removed } \\
(\mu \mathrm{mo} / \mathrm{g} \text { dry wt. cells })\end{array}$ \\
\hline Acinetobacter cireus IAM12341 & 920 \\
A. nicotianae IAM12342 & 714 \\
Bacillus licheniformis IAM11054 & 1092 \\
B. megaterium IAM1166 & 823 \\
B. subtilis IAM1026 & 740 \\
B. subtilis IAM11060 & 1106 \\
B. subtilis IAM1633 & 1145 \\
Brevibacterium helovolum IAM1637 & 876 \\
Corynebacterium equi IAM1038 & 1186 \\
C. gutamicum IAM12435 & 1185 \\
Deinococcus proteolyticus IAM12141 & 1180 \\
Micrococcus luteus IAM1056 & 1136 \\
Nocardia erythropolis IAM1399 & 1340 \\
\hline
\end{tabular}

Table 2. Removal of gold by gram-negative bacteria.

\begin{tabular}{cc} 
Species & $\begin{array}{c}\text { Au removed } \\
(\mu \mathrm{mo} / \mathrm{g} \text { dry wt. cells })\end{array}$ \\
\hline Citrobacter freundii IAM12471 & 941 \\
Escherichia coli IAM1264 & 1230 \\
Pseudomonas aureofaciens IAM12353 & 1000 \\
Pseudomonas maltophilia IAM1554 & 1259 \\
P. putida IAM1506 & 1104 \\
P. saccharophilia IAM1504 & 1418 \\
\hline
\end{tabular}

Table 3. Removal of gold by actinomycetes.

\begin{tabular}{cc}
\hline Species & $\begin{array}{c}\text { Au removed } \\
(\mu \mathrm{mo} / \mathrm{g} \text { dry wt. cells })\end{array}$ \\
\hline Streptomyces albogriseolus HUT6045 & 1188 \\
S. griseoflavus HUT6153 & 849 \\
S. hiroshimensis HUT6033 & 670 \\
S. viridochromogenes HUT6030 & 662 \\
\hline
\end{tabular}


Table 4. Removal of gold by fungi.

\begin{tabular}{cc} 
Species & $\begin{array}{c}\text { Au removed } \\
(\mu \mathrm{mo} / \mathrm{g} \text { dry wt. cells })\end{array}$ \\
\hline Aspergillus niger IAM2093 & 1085 \\
A. niger IAM2094 & 1193 \\
A. niger IAM2534 & 1251 \\
A. niger IAM3020 & 925 \\
A. niger AHU7120 & 1000 \\
A. niger AHU7296 & 888 \\
A. niger var Tieghem IAM2086 & 920 \\
A. niger var Tieghem var awamori IAM13839 & 1016 \\
Chaetomium globosum AHU9272 & 1221 \\
C. globosum AHU9427 & 1331 \\
Fusarium oxysporum IAM5009 & 920 \\
Giberella fujikuroi AHU9078 & 731 \\
Rhizopus japonicus IAM6002 & 987 \\
\hline
\end{tabular}

Table 5. Removal of gold by yeasts.

\begin{tabular}{cc} 
Species & $\begin{array}{c}\text { Au removed } \\
(\mu \mathrm{mo} / \mathrm{g} \text { dry wt. cells })\end{array}$ \\
Candida krusei AHU3993 & 1335 \\
C. utilis AHU3210 IAM4220 & 1193 \\
Cryptococcus albidus AHU3812 & 1251 \\
C. laurentii AHU3671 & 925 \\
Debaryomyces hansenii AHU3759 & 1000 \\
Hansenula anomala AHU3702 & 888 \\
H. saturnus AHU3003 & 920 \\
Pichia farinosa IAM12223 & 1016 \\
Saccharomyces cerevisiae AHU3818 & 1221 \\
S. cerevisiae IAM4512 & 1331 \\
S. uvarum AHU3978 & 920 \\
\hline Torulopsis aeria AHU3398 & 731 \\
\hline
\end{tabular}


Many positively-charged metal ions can be removed at the neutral $\mathrm{pH}$ using gram-positive bacteria and actinomycetes [10] [11] [12] [13] [14]. Negatively-charged gold (III) ions can be removed at an acidic $\mathrm{pH}$ using gram-negative bacteria [9] through biosorption. However, all metal ions tested can be removed in small amounts using yeasts and fungi [9]-[14]. Therefore, we investigated the removal of gold (III) using P. saccharophila IAM1504 in detail because this microorganism removed the largest amount of gold (III) among the tested microorganisms by biomineralization.

\subsection{Gold Removal as a Function of Time Using $P$, saccarophila IAM1504}

Gold (III) removal as a function of time using P. saccharophila IAM1504 was examined (Figure 1); the amount of gold removed increased with incubation time. Importantly, gold removal reached two equilibria. The first equilibrium state was at approximately $6 \mathrm{~h}$, and likely occurred by biosorption. Following this, the amount of gold removed increased again, and the solution color became darker, indicating biomineralization. The amount of gold removed using $P$. saccharophila IAM1504 by biosorption was relatively large [9], additionally the amount removed by biomineralization was much larger than biosorption.

\subsection{Effect of pH on Gold (III) Removal from Aqueous Gold (III) Using P. saccharophila Cells}

Gold (III) removal by $P$. sacharophila cells was significantly affected by $\mathrm{pH}$ (Figure 2). The maximum amount of gold removal occurred at $\mathrm{pH} 3.0$ (for $1 \mathrm{~h}$ ) or $\mathrm{pH} 3.5$ (for $72 \mathrm{~h}$ ).

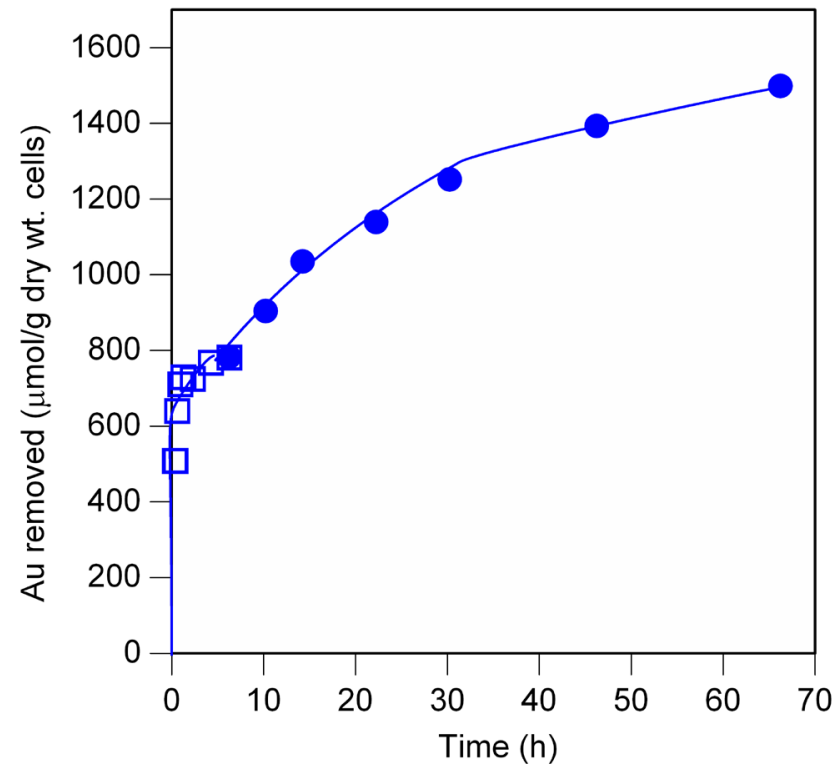

Figure 1. Gold (III) removed by $P$. saccharophila cells with the passage of time. Squares: within $6 \mathrm{~h}$ (biosorption); circles: contact for $>6 \mathrm{~h}$ (biomineralization). 


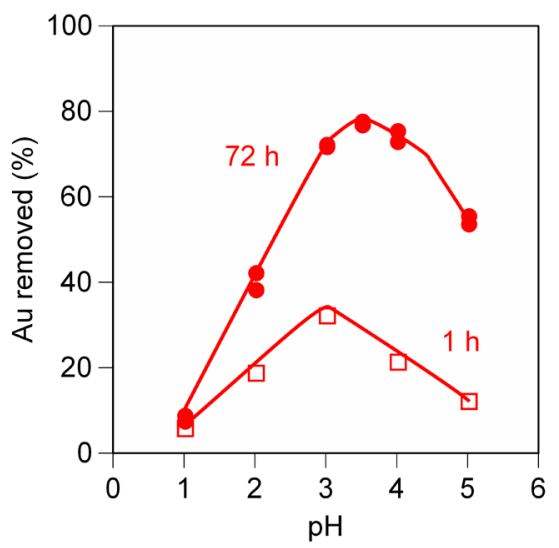

Figure 2. Effect of $\mathrm{pH}$ on gold (III) on the removal of gold (III) by $P$. saccharophila cells. Squares: for $1 \mathrm{~h}$ (biosorption); circles: contact for $72 \mathrm{~h}$ (biomineralization).

These results suggest that longer incubation time may change the reaction mechanism responsible for gold removal. The solution was nearly colorless after $1 \mathrm{~h}$. However, the color changed to violet, green during the $72 \mathrm{~h}$ incubation period. Owing to the tetrachloroaurate ion having a negative charge, gold (III) can be effectively removed at $\mathrm{pH} 3$ via biosorption [9]. It can also be reduced to atomic gold (0) by the activity of reductase in the presence of NADH [18] via biomineralization. Reduction occurred as shown in the following equation:

$$
2 \mathrm{Au}^{3+}+3 \mathrm{NADH} \rightarrow 2 \mathrm{Au}+3 \mathrm{NAD}^{+}+3 \mathrm{H}^{+}
$$

The equilibrium in an acidic solution is driven to the left; thus, suitable $\mathrm{pH}$ changed from 3.0 to 3.5 .

\subsection{Effect of Cell Amounts on gold (III) Removal from Aqueous Gold (III) Using P. saccharophila Cells}

The amount of gold (III) removed ( $\mu \mathrm{mol} / \mathrm{g}$ dry wt. cells) by $P$. saccharophila cells decreased slightly with an increase in the cell amount (Figure 3). However, increasing the cell amount of $P$. saccharophila IAM1504 increased the total gold (III) removal. About $1300 \mu \mathrm{mol}$ gold/g dry wt. cells were removed using $5.4 \mathrm{mg}$ dry wt. of $P$. saccharophila cells after $72 \mathrm{~h}$ incubation. Although the solution color did not change after $1 \mathrm{~h}$ incubation, the color changed to violet after $72 \mathrm{~h}$. Therefore, the amount of gold (III) removed by biomineralization was also much larger than that by biosorption.

\subsection{Absorption Spectrometry Analysis of Gold Removal Using Varying Cell Amount of P. saccharophila}

To distinguish between the biosorbed and the biomineralized gold, we analyzed the ionic gold (III) and colloidal atomic gold (0) by absorption spectrometry. The $300 \mathrm{~nm}$ absorbance peak decreased with increasing cell amount, while no peak was observed from from $500 \mathrm{~nm}$ to $550 \mathrm{~nm}$ (Figure 4). Broad peak was observed using C. krusei on similar experiment [19]. The $525 \mathrm{~nm}$ peak was iden- 
tified as zero valent gold [20] and the $500 \mathrm{~nm}-650 \mathrm{~nm}$ peak was small and broad because of the low solubility of gold (0). The amount of biosorbed gold (III) using $P$. saccharophilla cells was relatively large. Therefore, it can be inferred that gold reduction mainly occurred after being biosorbed on the cell surface of $P$. saccharophilla cells. On the other hand, the amount of biosorbed gold (III) using C. krusei cells was relatively small, and hence, it can be inferred that gold reduction mainly occurred in solution using C. krusei cells.

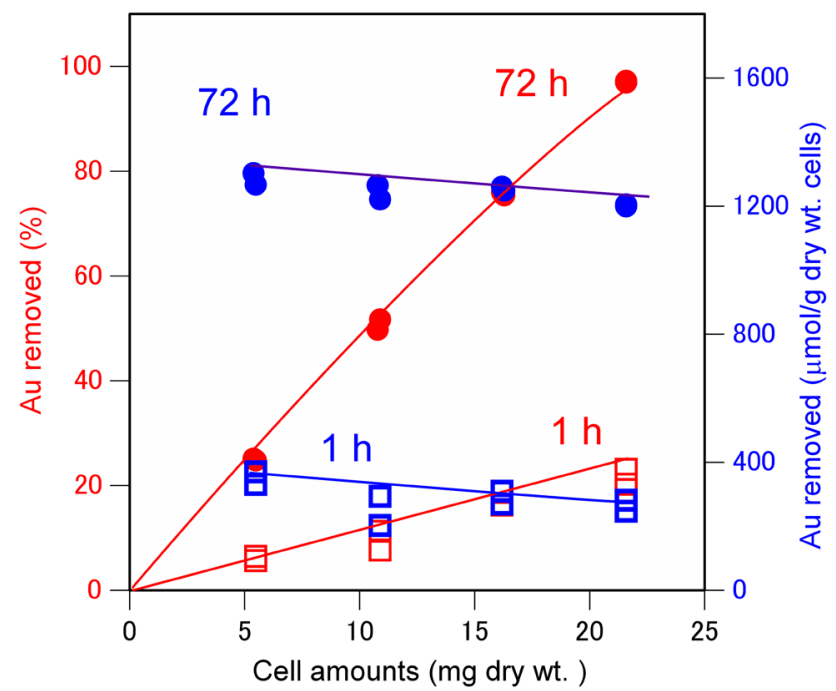

Figure 3. Effect of cell amounts on the removal of gold (III) by P. saccharophila cells. Red symbols: gold removed (\%); blue symbols: gold removed ( $\mu \mathrm{mol} / \mathrm{g}$ dry wt. cells); circles: contact $72 \mathrm{~h}$ (biomineralization); squares: $1 \mathrm{~h}$ (biosorption).

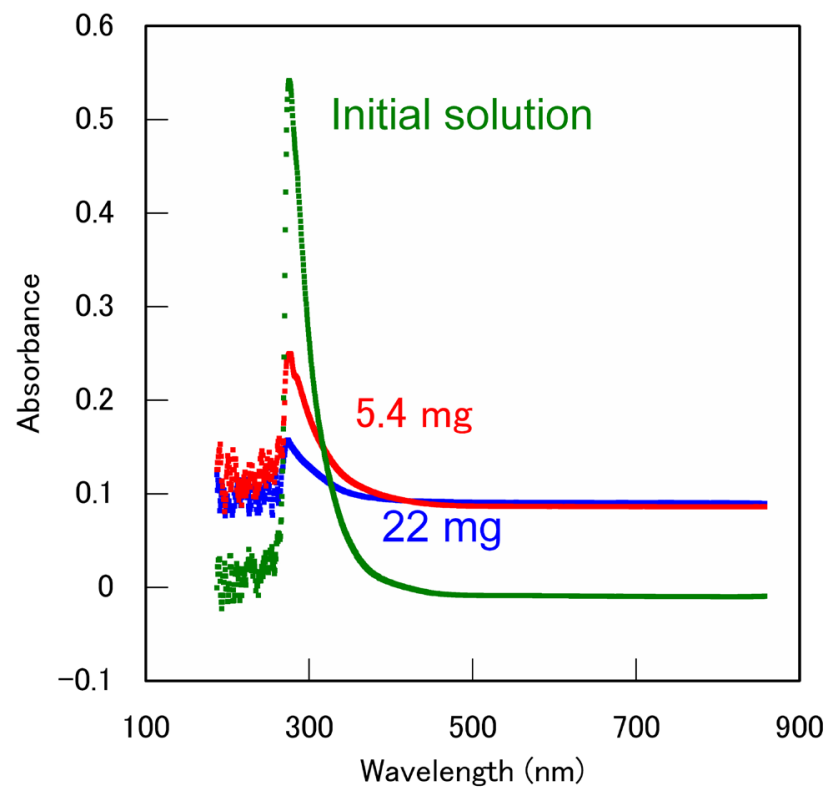

Figure 4. Absorption spectrometry analysis of gold removal using varying P. saccharophila IAM1504 amount. The gold removal conditions were identical to that in Figure 3 (incubation for $72 \mathrm{~h}$ ). Green line: initial amount of gold (III); red line: incubation with 5.4 mg dry wt. basis cells; blue line: $22 \mathrm{mg}$ dry wt. basis cells. 


\subsection{Effect of Gold Concentration on Gold (III) Removal from Aqueous Gold (III) Using P. saccharophila Cells}

To determine the maximum gold (III) removal ability at $\mathrm{pH} 4.0$, we examined the mechanism by which the gold (III) concentration affected the gold removal by $P$. saccharophila cells. The amount of gold removed ( $\mu \mathrm{mol} / \mathrm{g}$ dry weight cells) by $P$. saccharophila cells increased with increased gold concentration, whereas the ratio of total amount of gold to the gold concentration decreased (Figure 5). For gold (III) concentration of $200 \mathrm{mg} / \mathrm{L}(1020 \mu \mathrm{M}), 2500 \mu \mathrm{mol}$ gold/g dry cell wt. was observed at $\mathrm{pH}$ 4.0.

\subsection{SEM and XRF Analyses of Gold Removal Using $P$. saccharophila and $C$. krusei}

To confirm the biomineralized gold condition, the cell surfaces of $P$. saccharophila and C. krusei were analyzed via SEM and XRF. As shown in Figure 6, many particles were observed on the $P$. saccharophila cell surface. It can be inferred that these small particles are reduced gold after adsorption by $P$. saccharophila (Figure 7). In contrast, no particles were observed on the cell surfaces of C. krusei (Figure 8). However, as shown in Figure 9, peak was observed for reduced gold in the case of $C$. krusei. It can also be inferred that gold (III) is mainly reduced after being adsorbed on the $P$. saccharophila cells, whereas it is mainly reduced in the solution by $C$. krusei cells. This confirms the observations reported in Section 3.5.

Resting $P$. saccharophila cells ( $15 \mathrm{mg}$ dry wt. basis) contacted with the hydrogen tetrachloroaurate (III) solution ( $\mathrm{Au} 200 \mathrm{ppm}, \mathrm{pH} 4.0$ ) for $72 \mathrm{~h}$ at $30^{\circ} \mathrm{C}$. Magnification times was $20,000 x$.

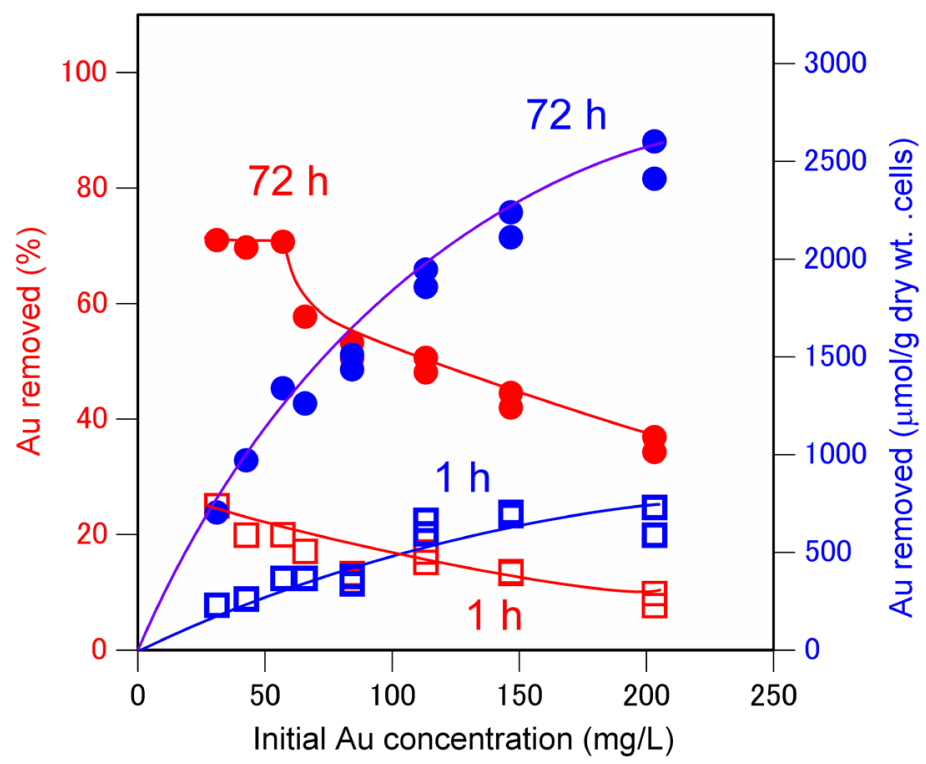

Figure 5. Effect of initial gold concentration on the removal of Au (III) by P. saccharophila cells. Red symbols: Au removed (\%); blue symbols: Au removed ( $\mu \mathrm{mol} / \mathrm{g}$ dry wt. cells); circle symbols: contact $72 \mathrm{~h}$ (biomineralization); square symbols: $1 \mathrm{~h}$ (biosorption). 


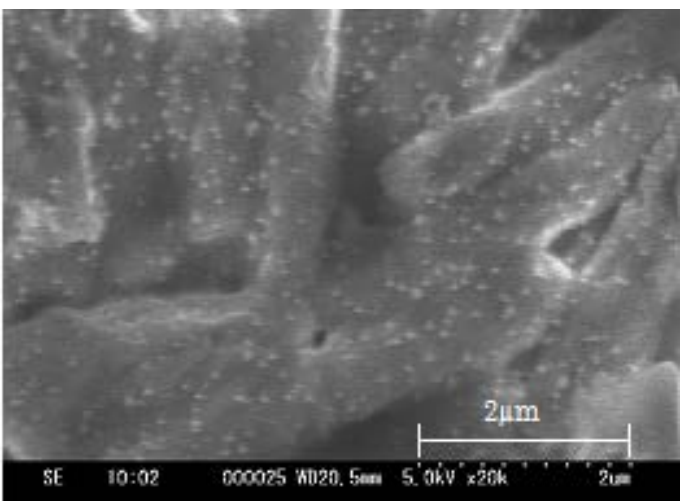

Figure 6. SEM image of $P$. saccharophila cells showing reduced gold particles.

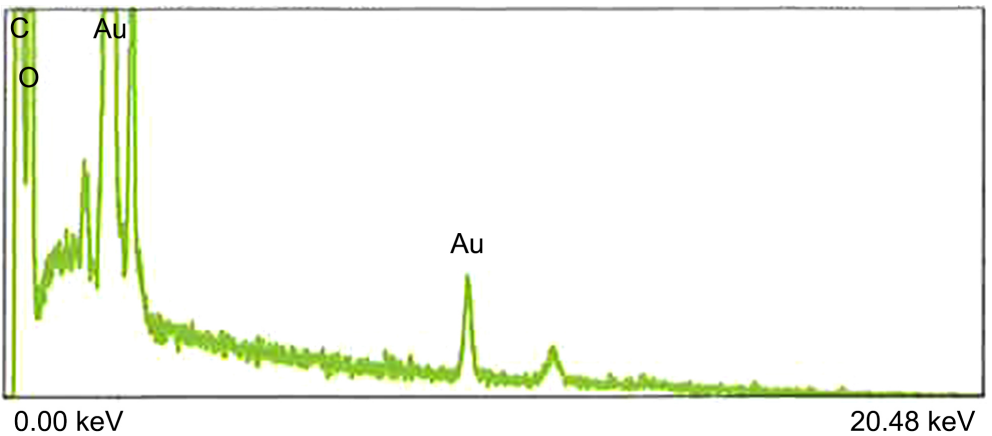

Figure 7. XRF spectrum of gold reduced on $P$. saccharophila cells.

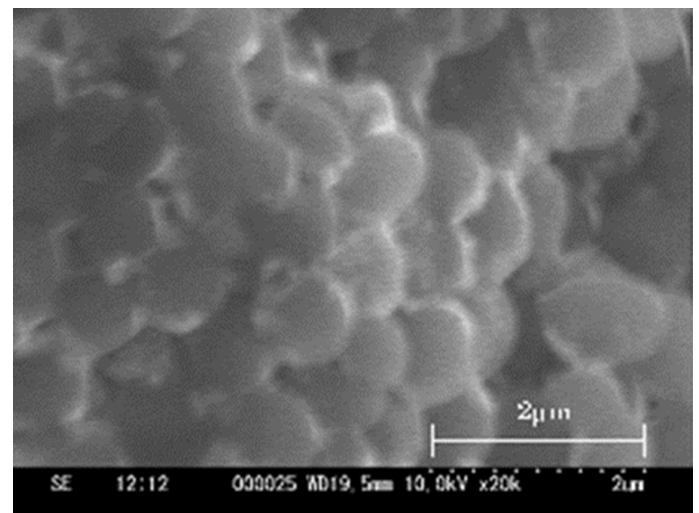

Figure 8. SEM image of $C$. krusei cells showing reduced gold particles.

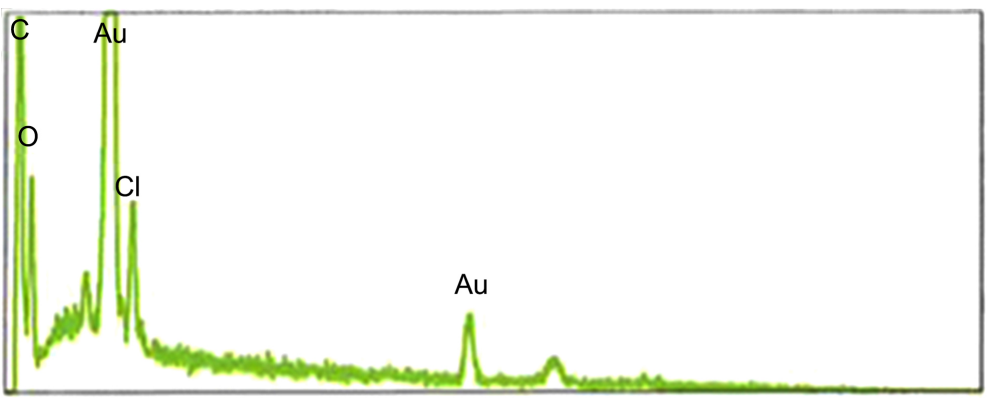

$0.00 \mathrm{keV}$

$20.48 \mathrm{keV}$

Figure 9. XRF spectrum of gold reduced on C. krusei cells. 
XRF analysis of dry cell surface of $P$. saccharophila were in contact with the the hydrogen tetrachloroaurate (III) solution (Au $200 \mathrm{ppm}, \mathrm{pH} 4.0$ ) for $72 \mathrm{~h}$ at $30^{\circ} \mathrm{C}$.

Resting C. krusei cells ( $15 \mathrm{mg}$ dry wt. basis) contacted with the hydrogen tetrachloroaurate (III) solution ( $\mathrm{Au} 200 \mathrm{ppm}, \mathrm{pH} 4.0$ ) for $72 \mathrm{~h}$ at $30^{\circ} \mathrm{C}$. Magnification times was 20,000x.

XRF analysis of dry cell surface of $C$. krusei were in contact with the hydrogen tetrachloroaurate(III) solution ( $\mathrm{Au} 200 \mathrm{ppm}, \mathrm{pH} 4.0$ ) for $72 \mathrm{~h}$ at $30^{\circ} \mathrm{C}$.

\section{Conclusions}

To optimize gold recovery, we first screened microorganisms for gold (III) removal from aqueous hydrogen tetrachloroaurate (III) solution ( $\mathrm{pH} 3.0$ ) after a $72 \mathrm{~h}$ incubation period at $30^{\circ} \mathrm{C}$. Gold was removed from the solution by all tested microorganisms. N. erythropolis IAM1399 among the gram-positive bacteria; E. coli IAM1264, P. maltophilia IAM1554, and P. saccharophila IAM1504 among the gram-negative bacteria; $A$. niger IAM2534, $C$. globosum IAM9272 and IAM9427 among the fungi; C. krusei AHU3993, C. utilis IAM4220, P. farinosa IAM12223, and $S$. cerevisiae AHU3818 among the yeasts removed over $1200 \mu \mathrm{mol}$ of gold/g dry cell wt.

The effects of incubation time, $\mathrm{pH}$, cell amount, and initial gold concentration on gold removal were analyzed by atomic absorption spectrometry. Absorption spectrometry analysis of the effect of cell amount and gold (III) concentration was also investigated. Additionally, cell surfaces of P. saccarophia and C. krusei were analyzed via SEM and XRF analysis. We observed that about half the amount of gold (III) was removed from the solution by biosorption after a short incubation time $(1 \mathrm{~h})$ and the remaining half was reduced from gold (III) to gold (0) by biomineralization on the cell surface by $P$. saccharophila IAM1504 after 72-hour incubation. Contrarily, small amounts of gold (III) were removed from the solution by biosorption after a short incubation time (1h) and a large amount of gold was reduced from the gold (III) to gold (0) by C. krusei AHU3993 in the solution by biomineralization after $72 \mathrm{~h}$ incubation.

Of all mentioned in this paper, we think $P$. saccharophila cells can remove the largest amount of gold from the aqueous hydrogen tetrachloroaurate (III) solution. Therefore, we will next examine the removal, recovery, and recycle of gold using immobilized $P$. saccharophila cells.

\section{Conflicts of Interest}

The authors declare no conflicts of interest regarding the publication of this paper.

\section{References}

[1] Suhr, M., Raff, J. and Pollmann, K. (2016) Au-Interaction of Slp1 Polymers and Monolayer from Lysinibacillus sphaericus JG-B53-QCM-D, ICP-MS and AFM as 
Tools for Biomolecule-Metal Studies. Journal of Visualized Experiments, 107, e53572. https://www.jove.com/t/53572/au-interaction-slp1-polymers-monolayer-from-lysin ibacillus-sphaericus https://doi.org/10.3791/53572

[2] Paez-Velez, C., Rivas, R.E. and Dussan, J. (2019) Enhanced Gold Biosorption of Lysinibacillus sphaericus CBAM5 by Encapsulation of Bacteria in an Alginate Matrix. Metals, 9, 818-827. https://www.mdpi.com/2075-4701/9/8/818 https://doi.org/10.3390/met9080818

[3] Gomes, N.C.M., Camargos, E.R.S., Dias, J.C.T. and Linardi, V.R. (1998) Gold and Silver Accumulation by Aspergillus niger from Cyanide-Containing Solution Obtained from the Gold Mining Industry. World Journal of Microbiology and Biotechnology, 14, 149. https://link.springer.com/article/10.1023/A:1008805423811

[4] Matsumoto, M. and Nishimura, Y. (1992) Recovery by Aspergillus oryzae of Gold from Waste Water from Gold Plating. Nippon Nougeikagakukaishi, 66, 1765-1770. (In Japanese)

https://www.jstage.jst.go.jp/article/nogeikagaku1924/66/12/66_12_1765/_article/-ch ar/ja/ https://doi.org/10.1271/nogeikagaku1924.66.1765

[5] Pethkar, A.V. and Paknikar, K.M. (1998) Recovery of Gold from Solutions Using Cladsporium cladosporioides Biomass Beads. Journal of Biotechnology, 63, 121-136. https://www.sciencedirect.com/science/article/abs/pii/S0168165698000789?via\%3Di $\underline{\text { hub }}$ https://doi.org/10.1016/S0168-1656(98)00078-9

[6] Karamuchka, V. and Gadd, G.M. (1999) Interaction of Saccharomyces cerevisiae with Gold: Toxicity and Accumulation. BioMetals, 12, 289-294.

https://link.springer.com/article/10.1023\%2FA\%3A1009210101628 https://doi.org/10.1023/A:1009210101628

[7] Hosea, M., Greene, B., McPherson, R., Henzl, M., Alexander, M.D. and Darnall, D.W. (1986) Accumulation of Elemental Gold on the Aalga Chlorella vulgaris. Inorganica Chimica Acta, 123, 161-165.

https://www.sciencedirect.com/science/article/abs/pii/S0020169300863392?via\%3Di $\underline{\text { hub }}$ https://doi.org/10.1016/S0020-1693(00)86339-2

[8] Kuyucak, N. and Volesky, B. (1989) Accumulation of Gold by Algal Biosorbent. Biorecovery, 1, 189-204.

[9] Tsuruta, T. (2004) Biosorption and Recycling of Gold Using Various Microorganisms. The Journal of General and Applied Microbiology, 50, 221-228.

https://www.jstage.jst.go.jp/article/jgam/50/4/50_4_221/_article https://doi.org/10.2323/jgam.50.221

[10] Tsuruta, T. (2005) Removal and Recovery of Lithium Using Various Microorganisms. Journal of Bioscience and Bioengineering, 100, 562-566 https://www.sciencedirect.com/science/article/abs/pii/S1389172305705107?via\%3Di $\underline{\text { hub }}$ https://doi.org/10.1263/jbb.100.562

[11] Tsuruta, T., Umenai, D., Hatano, T., Hirajima, T. and Sasaki, K. (2014) Screening Micro-Organisms for Cadmium Absorption from Aqueous Solution and Cadmium Absorption Properties of Arthrobacter nicotianae. Bioscience, Biotechnology, and Biochemistry, 78, 1791-1796.

https://www.tandfonline.com/doi/full/10.1080/09168451.2014.930321 
https://doi.org/10.1080/09168451.2014.930321

[12] Tsuruta, T. (2002) Removal and Recovery of Uranyl Ion Using Various Microorganisms. Journal of Bioscience and Bioengineering, 94, 23-28.

https://www.sciencedirect.com/science/article/abs/pii/S1389172302801116?via\%3Di hub https://doi.org/10.1016/S1389-1723(02)80111-6

[13] Tsuruta, T. (2003) Accumulation of Thorium Ion Using Various Microorganisms. The Journal of General and Applied Microbiology, 49, 215-218. https://www.jstage.jst.go.jp/article/jgam/49/3/49_3_215/_article https://doi.org/10.2323/jgam.49.215

[14] Tsuruta, T. (2007) Accumulation of Rare Earth Elements in Various Microorganisms. Journal of Rare Earths, 25, 526-532.

https://www.sciencedirect.com/science/article/abs/pii/S1002072107605560?via\%3Di $\underline{\text { hub }}$ https://doi.org/10.1016/S1002-0721(07)60556-0

[15] Conn, E.E., Stumpf, P.K., Bruening, G. and Doi, R.H. (1987) Outlines of Biochemistry. Wiley, New York.

[16] Fischer, W., Ishizuka, I., Landgraf, H.R. and Herrmann, J. (1973a) Glycerophosphoryl Diglucosyl Diglyceride, a New Phosphoglycolipid from Streptococcus. Biochimica et Biophysica Acta, 296, 527-545.

https://www.sciencedirect.com/science/article/abs/pii/0005276073901136?via\%3Dih $\underline{\mathrm{ub}}$ https://doi.org/10.1016/0005-2760(73)90113-6

[17] Fischer, W., Landgraf, H.R. and Herrmann, J. (1973b) Phosphatidyldiglucosyl Diglyceride from Streptococci and Its Relationship to Other Polar Lipids. Biochimica et Biophysica Acta, 306, 353-367.

https://www.sciencedirect.com/science/article/abs/pii/0005276073901744?via\%3Dih $\underline{\mathrm{ub}}$ https://doi.org/10.1016/0005-2760(73)90174-4

[18] Paul, R.J. and Schneckenburger, H. (1996) Oxygen Concentration and the Oxidation-Reduction State of Yeast: Determination of Free/Bound NADH and Flavins by Time-Resolved Spectroscopy. Naturwissenschaften, 83, 32-35.

https://link.springer.com/article/10.1007\%2FBF01139308 https://doi.org/10.1007/BF01139308

[19] Maeda, I. and Tsuruta, T. (2020) Microbial Gold Biosorption and Biomineralization from Aqueous HAuCl4 Solution. Minerals, 10, 285-293.

https://www.mdpi.com/2075-163X/10/3/285

https://doi.org/10.3390/min10030285

[20] Doremus, R.H. (1964) Optical Properties of Small Gold Particles. The Journal of Chemical Physics, 40, 2389-2396. https://aip.scitation.org/doi/10.1063/1.1725519 https://doi.org/10.1063/1.1725519 